Jurnal Info Kesehatan

Vol 18, No 2, December 2020, pp. 171-181

P-ISSN 0216-504X, E-ISSN 2620-536X

DOI:10.31965/infokes. Vol18Iss2.396

Journal homepage:http://jurnal.poltekeskupang.ac.id/index.php/infokes

\title{
Factors Affecting Nurse Caring Behavior
}

Yoany M. Vianney Bita Aty ${ }^{1 a^{*}}$, Elisabeth Herwanti ${ }^{1 b}$, Aemilianus Mau ${ }^{1 \mathrm{c}}$, M. Ibraar Ayatullah $^{2 \mathrm{~d}}$, Fialisa Asriwhardani ${ }^{3 \mathrm{e}}$

${ }^{1}$ Department of Nursing, Poltekkes Kemenkes Kupang, Kupang, East Nusa Tenggara, Indonesia

${ }^{2}$ Department of Dental Health, Poltekkes Kemenkes Kupang, Kupang, East Nusa Tenggara, Indonesia

${ }^{3}$ Emergency Nursing Erasmus Master Student of University of Argarve, Faro, Portugal

a Email address: vivi_aty@yahoo.co.id

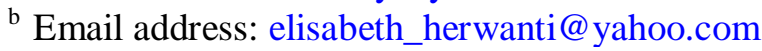

c Email address: mauaemilianus@yahoo.com

${ }^{\mathrm{d}}$ Email address: mibraarayatullah21@gmail.com

e Email address: a72448@ualg.pt

Received: 15 April $2020 \quad$ Revised: 25 December 2020 Accepted: 26 December 2020

\section{Abstract}

Caring behavior is the center of nursing practice, a very dynamic technique, where nurses work with care for their patients. The better the nurse's caring behavior in providing nursing services to patients, the better the level of patient satisfaction with nursing services. Currently, there are nurses and other health workers who are not friendly enough in providing services. The objective of this study is to determine the factors that influence the caring behavior of nurses who work at the Regional Public Hospital of East Nusa Tenggara Province, which are age, gender, education, training, employment status, marital status, work stress, work motivation and respect for nurse caring behavior. This research is a type of quantitative research with a crosssectional design. The population is all nurse administrators who work in 5 Regional Public Hospital of East Nusa Tenggara Province, amounting to 803 people. The number of samples of 161 nurses was taken by simple random sampling. Determination of the number of samples using the rule of thumb formula, namely 5 independent variables x $32=160$ respondents. The instrument used was a questionnaire. Bivariate data analysis at a significant level of $5 \%(\alpha=$ $0.05)$ using the Pearson Chi-Square test. Multivariate analysis using logistic regression test. The results showed that the factors that influence nurse caring behavior are employment status $(\mathrm{p}$ value 0.001 ) and motivation ( $\mathrm{p}$ value 0.005 ). The results of the Odds Ratio (Exp. B) show that employment status is a determinant factor in the caring behavior of nurses in East Nusa Tenggara with an OR of 3,634, which means that nurses with civil servant status are 3.6 times more likely to behave in caring than nurses with contract employment status. It is suggested to examine other factors that can influence the caring behavior of nurses who work at the Regional Public Hospital of East Nusa Tenggara Province.

Keywords: Behavior, Nurse, Caring, Hospital

*Corresponding Author:

Yoani M. Vianney Bita Aty

Department of Nursing, Poltekkes Kemenkes Kupang, Kupang, East Nusa Tenggara, Indonesia.

Piet A. Tallo Street-Liliba, Kupang, East Nusa Tenggara.

Email: vivi_aty@yahoo.co.id

(CThe Author(s) 2020. This article is distributed under the terms of the Creative Commons Attribution 4.0 International License (http://creativecommons.org/licenses/by/4.0/), which permits unrestricted use, distribution, and reproduction in any medium, provided you give appropriate credit to the original author(s) and the source, provide a link to the Creative Commons license, and indicate if changes were made. The Creative Commons Public Domain Dedication waiver (http://creativecommons.org/publicdomain/zero/1.0/) applies to the data made available in this article, unless otherwise stated. 


\section{INTRODUCTION}

Excellent service is the most important thing done in hospitals and other health facilities. Hospitals are required to be able to provide quality health services to patients. One of the manifestations of this quality service is the caring attitude that nurses have when providing health services to the patients they care for. Caring is the basis and central in providing nursing care. This behavior causes nurses to understand and be able to provide help to patients both physically and psychologically. Caring behavior enables the fulfillment of essential needs for patients (Andersson, 2015). The quality of nursing service is reflected in the implementation of professional nursing care. Professional and qualified nurses must have hard skills and soft skills, because a person's success in the world of work is influenced by soft skills (80\%) and hard skills (20\%). Soft skills include the ability to communicate, build relationships with others, the ability to understand others, responsibility, cooperation, empathy and caring (Ariani \& Aini, 2019).

The reality currently faced is the ability of nurses to provide services at the Regional Public Hospital in Kupang City. The results of the study show that 100 respondents who were asked for their opinion regarding the ability of nurses to provide services at the Regional Public Hospital of Kupang City showed that the ability of nurses to provide services to 10 people was not good (10\%) (Weraman \& Adoe, 2016). Service conditions like this will have an impact on patient and nurse satisfaction because nurses provide nursing care holistically (Aiken, et al., 2012) and will affect public perceptions of the caring behavior of nurses who are lacking in nursing services (Aiken, et. al., 2014). This condition is a phenomenon that occurs in almost all hospitals throughout Indonesia. The results of the study showed that most of the nurses were less caring which had an impact on the dissatisfaction of service felt by patients (Mailani \& Fitri, 2017).

The client assesses that the nurse's caring behavior is in sufficient category and the nurse can apply caring behavior to the client during nursing practice in the hospital, but it is not optimal. Nurses need to improve caring behavior in each factor, so that it is expected to be the basis for forming nurse caring behavior guidelines and guidelines for fulfilling spiritual needs in (Firmansyah, et. al., 2019).

Behavior that is conducting medical actions such as: measuring vital signs is almost $100 \%$, clinically skilled, observing the effects of drugs, reporting the patient's condition to the doctor. The patient views that the results of the Mau, et. al., research (2017) on the effect of coaching and mentoring on changes in nurse caring behavior, in the first two weeks of training there was an increase in caring behavior, but after the next four weeks, the caring behavior of nurses returned to normal (Mau, et. al., 2020).

Factors that influence nurse caring behavior are individual, psychological, and organizational factors. Individual factors include demographics (age, gender, education, years of service, marital status and employment status), abilities, and skills. Psychological factors include: attitudes, personality, learning, and motivation. Organizational factors include: resources, leadership, rewards, structure, and job design. Organizational culture factors include: communication, reward, decision making, risk taking, cooperation, management (Kusnanto, 2019).

Caring behavior is the center of nursing practice, a very dynamic technique, where nurses work with care for their patients. The better the caring behavior of nurses in providing nursing services to patients, the better the level of patient satisfaction with nursing services will be (Mailani \& Fitri, 2017). The high interaction performed by nurses will certainly increase the trusting relationship between patients and nurses. It is 
necessary to build the ability to communicate both verbally and nonverbally so that patients feel comfortable when being treated by patients.

The results of research conducted by Weraman and Adoe, found that nurses and other health workers were still not friendly in providing services, the services applied by officers were not optimal which resulted in the length of administrative services so that medical treatment was slow (Weraman \& Adoe, 2016). Thus, it is necessary to conduct research on the factors that influence the caring behavior of nurses who work at the Regional Public Hospital of East Nusa Tenggara Province in 2019. The general objective of the study is to determine the factors that influence the caring behavior of nurses who work at the Regional Public Hospital of East Nusa Tenggara Province.

\section{RESEARCH METHOD}

This type of research is quantitative with a cross-sectional design. The variables in this study consisted of independent variables, which were the factors that influenced the caring behavior of nurses and the dependent variable was the caring behavior of nurses. The population in the study were all nurses who worked in 5 (five) Regional Public Hospital of East Nusa Tenggara Province, totaling 803 people. Total sample of 161 nurses who were taken by simple random sampling. Determination of the number of samples in this study using the rule of thumb formula for multivariate analysis: $5-50$ times the number of independent variables. In this study, researchers used the rule of thumb: 5 independent variables x $32=160$ respondents.

The hospital was determined randomly based on the island/mainland. Flores Island has one hospital, Timor Island has one hospital, Sumba Island has one hospital, Alor Island, Sabu, Rote one hospital. Inclusion criteria: nurse, willing to be a respondent, minimum education Diploma III of Nursing, not on leave. The exclusion criteria were nurses who resigned during the data collection process. The research was conducted in September-October 2019 in all Regional Public Hospital of East Nusa Tenggara Province.

The research instrument that the author uses is a questionnaire. There are five research instruments that have been tested for validity and reliability by researchers. The nurse's caring behavior instrument was taken from the Wolf's Caring Behaviors Inventory in 1988 which had its validity and reliability tested with a Cronbach alpha value of 0.81-0.92 and had a reliability of 0.96 (Wolf, et. al., 1998). Job stress was measured through a modified questionnaire from the stress profile questionnaire made by Smith-Miller scale (the Miller-Smith Lifestyle Assessment Inventory) (Miller, 1998). The work stress instrument in this study had been tested for its validity and reliability by Ilmi in 2002 on 5 nurses at Dr. Soetomo Surabaya and 5 nurses at Regional Public Hospital of Ulin Banjarmasin, with a $\mathrm{p}$ value $<0.05$, and a Cronbach alpha test value 0.90 (Ilmi, 2002). Work motivation has been tested by Wahyudi (2016), where the Cronbach alpha value is 0.87 , thus this research instrument is said to be valid and reliable. Wahyudi (2016) tested the validity and reliability of the award/reward instrument, where the Cronbach alpha value was 0.93, thus this research instrument was said to be valid and reliable.

The data collection procedure included arranging research permits and ethical permits and then giving directions to the enumerators (head of the room) at each hospital to equalize perceptions about how data was collected. Data collection began with the observation of the respondent's behavior without notification that the respondent was assessed by the head of the room for caring behavior. After the 
observation, it was followed by an explanation of the research and the signature of the executive nurse who was involved in the research, and filling in the instruments for individual factors, work stress, work motivation, and appreciation.

The analysis in this study was a univariate analysis to describe each of the independent and dependent variables. Bivariate analysis was employed to examine the relationship between two variables (independent and dependent) at a significant level of $5 \%(\alpha=0.05)$. The type of test was determined based on the data scale and data normality. In this study, the distribution of abnormal data was obtained so that the tests used were: the influence of age, gender, education, tenure, work status and marital status, marital status, work motivation, work stress, work motivation, work stress, appreciation, on nurse caring behavior using the Pearson Chi-Square test. The influence of work motivation, job stress, rewards, organizational culture on nurse caring behavior using the Pearson Chi-Square test. Multivariable analysis using logistic regression test to determine the determinant factors that influence nurse caring behavior. This research was declared ethical through a certificate of ethical worthiness No. LB.02.02/I/0027.2019 issued by the ethics commission of the Health Polytechnic of the Ministry of Health, Kupang.

\section{RESULTS AND DISCUSSION}

Table 1. Caring Behavior of Implementing Nurses at the Regional Public Hospital of East Nusa Tenggara Provincein 2019

\begin{tabular}{lcc}
\hline Category & n & \% \\
\hline Caring & 85 & 52,8 \\
\hline Not Caring & 76 & 47,2 \\
\hline Total & 161 & 100 \\
\hline
\end{tabular}

Table 1 shows that some of the nurse administrators at the Regional Public Hospital of East Nusa Tenggara Provincewho behave caring (52, 8\%).

Table 2. The Effect of the Characteristics of Implementing Nurses on Caring Behavior in the Regional Public Hospital of East Nusa Tenggara Provincein 2019

\begin{tabular}{|c|c|c|c|c|c|c|}
\hline \multirow{2}{*}{ Characteristics } & \multirow{2}{*}{$\mathbf{n}$} & \multirow{2}{*}{$\%$} & \multirow{2}{*}{$p$ value } & \multirow{2}{*}{ OR } & \multicolumn{2}{|c|}{$95 \%$ CI for $\operatorname{Exp}(\mathrm{B})$} \\
\hline & & & & & Lower & Upper \\
\hline \multicolumn{7}{|l|}{ Age (year) } \\
\hline Early Adult (26-35) & 102 & 63,4 & \multirow[t]{3}{*}{3,26} & \multirow[t]{3}{*}{0,714} & \multirow[t]{3}{*}{0,373} & \multirow[t]{3}{*}{1,365} \\
\hline Late Adult (36-45) & 49 & 30,4 & & & & \\
\hline Early Elderly (46-55) & 10 & 0,62 & & & & \\
\hline \multicolumn{7}{|l|}{ Gender } \\
\hline Male & 17 & 10,6 & \multirow[t]{2}{*}{0,990} & \multirow[t]{2}{*}{1,007} & \multirow[t]{2}{*}{0,368} & \multirow[t]{2}{*}{2,755} \\
\hline Female & 144 & 89,4 & & & & \\
\hline \multicolumn{7}{|l|}{ Education } \\
\hline Diploma III of Nursing & 117 & 72,7 & \multirow[t]{3}{*}{0,935} & \multirow[t]{3}{*}{0,972} & \multirow[t]{3}{*}{0,485} & \multirow[t]{3}{*}{1,945} \\
\hline Nurse & 43 & 26,7 & & & & \\
\hline Master of Nursing & 1 & 0,6 & & & & \\
\hline \multicolumn{7}{|l|}{ Caring Training } \\
\hline Yes & 20 & 12,4 & \multirow[t]{2}{*}{0,107} & \multirow[t]{2}{*}{2,300} & \multirow[t]{2}{*}{0,836} & \multirow[t]{2}{*}{6,327} \\
\hline No & 141 & 87,6 & & & & \\
\hline \multicolumn{7}{|l|}{ Years of Service } \\
\hline$<10$ years & 93 & 57,8 & \multirow[t]{2}{*}{0,028} & \multirow[t]{2}{*}{0,491} & \multirow[t]{2}{*}{0,260} & \multirow[t]{2}{*}{0,927} \\
\hline $10-20$ years & 61 & 37,9 & & & & \\
\hline
\end{tabular}


Aty, Y. M. V. B., Herwanti, E., Mau, A., Ayatullah, M. I., \& Asriwhardani, F. (2020). Factors Affecting Nurse Caring Behavior. JURNAL INFO KESEHATAN, 18(2), 171-181. https://doi.org/10.31965/infokes.Vol 18/ss2.396

175

\begin{tabular}{|c|c|c|c|c|c|c|}
\hline$>20$ years & 7 & 4,3 & & & & \\
\hline \multicolumn{7}{|l|}{ Employment Status } \\
\hline Civil Servant & 101 & 62,7 & 0,000 & 0,248 & 0,124 & 0,499 \\
\hline Contract/Honorarium & 60 & 37,3 & & & & \\
\hline \multicolumn{7}{|l|}{ Marriage Status } \\
\hline Married & 118 & 73,3 & 0,116 & 0,563 & 0,275 & 1,153 \\
\hline Not Married & 43 & 26,7 & & & & \\
\hline
\end{tabular}

The results of statistical analysis with the Pearson Chi-Square test showed that the results that affect caring behavior are the tenure $(\mathrm{p}$ value $=0.028)$ and employment status ( $\mathrm{p}$ value $=0,000)$, while gender, education, training, marital status does not have an effect. The highest OR value is the tenure, which is 0,491 , which means that nurses with a higher tenure have a $0.491 \mathrm{x}$ greater chance of caring behavior.

Table 3. The Influence of Job Stress Factors for Implementing Nurses on Caring Behavior in the Regional Public Hospital of East Nusa Tenggara Provincein 2019

\begin{tabular}{|c|c|c|c|c|c|c|}
\hline \multirow[t]{2}{*}{ Category } & \multirow[t]{2}{*}{$\mathrm{n}=161$} & \multirow[t]{2}{*}{$\%$} & \multirow[t]{2}{*}{$p$ value } & \multirow[t]{2}{*}{ OR } & \multicolumn{2}{|c|}{$\begin{array}{l}95 \% \text { CI for } \operatorname{Exp} \\
\text { (B) }\end{array}$} \\
\hline & & & & & Lower & Upper \\
\hline Stress & 79 & 49,1 & & & & \\
\hline Not Stress & 82 & 50,9 & 0228 & 0,682 & 0,366 & 1,271 \\
\hline Total & 161 & 100 & & & & \\
\hline
\end{tabular}

Based on the Pearson Chi-Square analysis, there is no influence between the work stress of nurses on caring behavior.

Table 4. The Influence of Work Motivation Factors for Implementing Nurses on Caring Behavior in the Regional Public Hospital of East Nusa Tenggara Provincein 2019

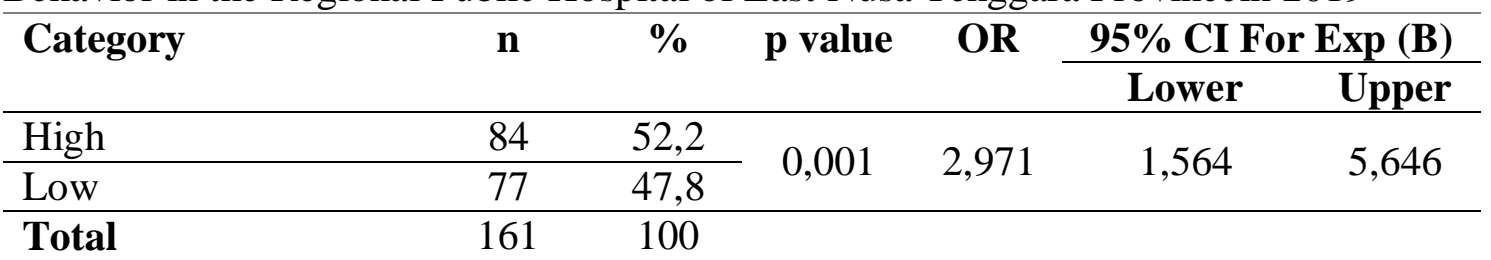

Based on Pearson Chi-Square analysis, there is an influence between the work motivation of nurses on caring behavior $(\mathrm{p}=0.001)$. The OR value is 2,971 , which means that nurses with high work motivation have a 2,971 chance of caring behavior.

Table 5. The Influence of Implementing Nurse Appreciation Factors on Caring Behavior in the Regional Public Hospital of East Nusa Tenggara Provincein 2019

\begin{tabular}{lcccccc} 
Category & n & \% & p value & OR & \multicolumn{2}{c}{ 95\% CI for Exp (B) } \\
\cline { 1 - 2 } & & & & & Lower & Upper \\
\hline High & 85 & 52,8 & 0,875 & 0,910 & 0,493 & \\
\cline { 1 - 3 } Tow & 76 & 47,2 & & & & 1,703 \\
\hline Total & 161 & 100 & & & & \\
\hline
\end{tabular}

Based on the Pearson Chi-Square analysis, there is no effect between the rewards received by nurses on caring behavior $(\mathrm{p}=0.875)$.

The results of statistical tests using multiple regression tests with the backward method illustrate that the factors that influence the caring behavior of nurses are employment status ( $p$ value 0.000 ) and motivation ( $p$ value 0.005 ). Based on the results of the Odds Ratio (Exp B), employment status is a determinant factor in the caring behavior of nurses in East Nusa Tenggara with an OR of 3,634, which means that 
nurses with civil servant status have a 3.6 times chance of caring behavior compared to nurses who have contract employee status/honorarium.

The results of statistical tests showed that the factors that influence nurse caring behavior are employment status ( $p$ value 0.001 ) and motivation ( $p$ value 0.005). Based on the results of the Odds Ratio (Exp. B), employment status is a determinant factor in the caring behavior of nurses in East Nusa Tenggara with an OR of 3,634, which means that nurses with civil servant status have 3.6 times more chance of caring behavior compared to nurses who have contract/honorarium employment status.

\section{a. Caring Behavior}

The results showed that nurses at the Regional Public Hospital of East Nusa Tenggara Province who had caring behavior were more caring than those who did not, although the difference was not too big. These results are supported by research results which state that nurses provide comfort, good relationships, and provide humanistic care to patients, so that patients feel satisfied with the services provided by nurses (Calong \& Soriano, 2018). It is supported by the results of research conducted by Cheruiyot which found that caring behavior was caused by nurses working hard to keep patients alive. Lack of caring behavior due to nurses feeling frustrated, inadequate service and often neglecting patients (Cheruiyot \& Brysiewicz, 2019).

Caring behavior is formed as a result of patient-focused care thereby strengthening the relationship between nurse and patient. Nurses have begun to realize the need to behave caring, begin to realize their duties and responsibilities as nurses. The focus of care is patient, thus increasing the intensity of the meeting between nurse and patient.

Caling in 2018 explained that nurses who care for patients will increase satisfaction with the care services provided. The nurse assessed that she had performed caring correctly on the patient as evidenced by the increasing service satisfaction received by patients (Calong \& Soriono, 2018).

In the Regional Public Hospital of East Nusa Tenggara Province, the number of nurses has also started to follow service standards because in general this hospital has been and is in the process of accreditation. This has an effect on the quality of services provided to patients, where nurses prioritize services to meet patient needs.

\section{b. Influence of Characteristic Factors on Caring Behavior}

The results showed that the characteristics of nurses in the Regional Public Hospital of East Nusa Tenggara Province including age, marital status, education, training had no relationship with caring behavior. Factors that influence the caring behavior of nurses are tenure and employment status.

The results of the study are not in accordance with the research conducted by Geyer in 2017 which found that nurses who were caring towards patients were mostly women, who had stronger feelings of empathy, 30-49 years old which is an adult showing emotional maturity. However, the length of work is in accordance with Geyer's 2017 research which explains that the work experience is over 20 years. This long work experience has an effect on high work quality, so that caring behavior is getting better (Geyer, et. al, 2017).

Researchers argue that age cannot guarantee nurse caring behavior to be good, it really depends on each individual. The gender of the nurse is not related to caring behavior because they both have the same role when caring for patients, so it cannot be distinguished which one is better.

A high level of education increases the motivation of nurses to be able to further improve the quality of nursing care services, especially patient personal hygiene. 
However, this is not in accordance with the results of the research, this is because the character of the people of East Nusa Tenggara who always speak with a harsh tone, which of course has been internalized in the person of everyone.

Marital status has no relationship with nurse caring behavior. This is in accordance with the research conducted by Anggoro Wisnu in 2018 which found that there was no relationship between marital status and caring behavior of nurses at the Regional Public Hospital of Dr. H. Soewondo Kendal (Anggoro, et. al, 2018).

The treatment given to patients who are treated at the Regional Public Hospital of East Nusa Tenggara Province is no different and is given as is in accordance with previous habits and work culture in the hospital, so that the nurse's marital status does not affect caring behavior.

\section{c. The Effect of Nurse Work Stress on Caring Behavior}

The results showed that most of the nurses who worked at the Regional Public Hospital of East Nusa Tenggara Province did not experience work stress. Based on the statistical analysis using Chi-Square, it was found that job stress did not affect caring behavior. This result is supported by Hangewa's research in 2020 which explains that there is no relationship between work stress and caring behavior (Hangewa, et. al, 2020). This is also in contrast to research conducted by Lestari, et al in 2010 which found that there is a correlation between the level of work stress of nurses and the caring behavior of nurses in the Inpatient Hospital of the Hospital. The higher the level of work stress for nurses in conducting their duties as a nurse, the less the caring they show, and vice versa, the lower the level of work stress of the nurses, the better the caring behavior of nurses given to patients (Lestari, et. al., 2010). The results of the study are inconsistent with the findings about work stress experienced by nurses due to many factors, which are conflicts with colleagues, lack of knowledge and skills. This situation affects the caring behavior of the patient. Job stress can be overcome by providing additional knowledge about nursing skills, workshops, conflict management, relaxation techniques (Sarafis, 2016). This result is also supported by research conducted by Rizkianti in 2019 which found that there was no relationship between caring behavior and work stress of nurses. The results of this study also indicate that the low level of care of nurses by patients has not been fully influenced by the workload and work stress of nurses (Rizkianti \& Haryani, 2020).

High work stress will lead to poor communication between nurses and patients, failure of collaboration between nurses and patients, high dropout/turnover, and a sense of job dissatisfaction with nurses. This statement is of course contrary to the results obtained. This could be due to the habit of interacting with nurses who work at the Regional Public Hospital of East Nusa Tenggara Province with a loud tone of voice, so that patients easily adapt to this condition. Most of the nurses have never received training on caring and the working period is mostly less than 10 years.

\section{d. The Influence of Work Motivation Factors on Caring Behavior of Implementing Nurses}

The results of this research are that the work motivation of the nurses at the Regional Public Hospital of East Nusa Tenggara Province is mostly categorized as high motivation. What motivates the nurse to work is in performing her duties and responsibilities as a nurse, including providing assistance to patients, communicating and providing information to patients. The results showed that there was an influence with caring behavior and multiple logistic regression on nurses' work motivation also had an influence on caring behavior. This result is supported by research conducted by 
Prihandhani which found that there is a significant relationship between the work motivation of nurses and the caring behavior of nurses in the inpatient room of Wisma Prashanti Tabanan General Public Hospital. The higher the work motivation, the better the nurse's caring behavior. Likewise, vice versa, the lower the work motivation, the less caring behavior of nurses. Each individual has a drive that directs the behavior of nurses to work differently so that in revealing caring behavior that nurses have to clients will also be different (Prihandhani \& Kio, 2019)

Another result is that there is a significant relationship between motivation and nurse caring behavior. Nurses who have high motivation also perform caring behavior. In order for caring to be implemented, it requires high work motivation and a conducive work environment (Demur, et. al., 2019). Nurses' motivation in implementing caring behavior is high, but there are still nurses who are not good at caring behavior. This is because the workload of nurses is excessive or overload causes nurses to care less about patients (Demur, et. al., 2019).

Researchers argue that motivation becomes the driving force that comes from within humans to act or behave caring. This behavior is very personal, so caring disclosures are different for each client. Motivation can direct the behavior of nurses in providing complete nursing care services to patients. The better the motivation, the higher the service quality.

Nurses who work in hospitals in the province of East Nusa Tenggara need to continue to increase their motivation to behave in caring, so that it will encourage this desire to provide excellent service to patients so that patients will feel satisfied with the services provided.

\section{e. The Influence of Appreciation Factors on Caring Behavior of Implementing Nurses}

The results showed that there was no influence between the rewards received by nurses on the caring behavior of nurses in the Regional Public Hospital of East Nusa Tenggara Province. These results are in accordance with research (Supriatin, 2015) which explains that there is a relationship between rewards in the form of rewards and caring behavior. Rewards are needed to increase motivation and performance. Lack of appreciation for outstanding nurses and caring nurses can reduce nurses' motivation to care for clients.

This result is also in line with research conducted by Sumarni, 2017 which states that there is no relationship between reward and caring behavior of the implementing nurses. It happens because the reward system is influenced by other factors, which are environmental, psychological, knowledge, skills, educational level (Sumarni \& Naili, 2017). Rewards can be in the form of opportunities to participate in self-development through training, regular seminars, giving praise and opportunities to provide input on organizational policies.

\section{f. Determinant Factors Affecting Caring Behavior}

Based on the results of the logistic regression test, it is found that employment status is a determinant factor that affects caring behavior, which based on OR, employment status has an opportunity for caring behavior. According to the data obtained by some of the nurses who are implementing nurses with non-civil servant status, the results of this study also show that some nurses at the Regional Public Hospital of East Nusa Tenggara Province lack caring behavior. Caring behavior will also be formed from the example given by the leadership to its staff in providing nursing services to patients in the form of self-care, the ability to make decisions, the 
ability to be able to organize themselves, build relationships with other people. Training to be responsible in doing work, being an advocate patient.

This leadership support will certainly improve the soft skills of nurses to be able to apply nursing services whole heartedly to patients (Dyess, et. al., 2015). Based on the results of this study, efforts are needed to improve the employment status of the contract/honorarium. The results of this study are different from research (Zees, 2012) which in his research said that the determinant factors of caring for nurses in nursing services are training, communication, rewards, decision making, management.

The people of East Nusa Tenggara feel very confident when they hold their employment status as a State Civil Apparatus. This situation will affect the behavior of daily life when caring for patients, where they are more confident when doing treatment. This is in contrast to nurses who are not state civil servants. The assumption that there is no need to provide maximum care to patients, because they do not have a full sense of responsibility. The limitation in the East Nusa Tenggara research is that it is an archipelago, so data collection was administered by enumerators who were equipped with long-distance communication so that there is a difference in perception when filling out the questionnaire. As a result, the distributed questionnaire was not in accordance with the research objectives so that the data was not analyzed. Solutions for future research enumerators are trained 3-4 times to understand the data retrieval process.

\section{CONCLUSION}

Some nurse administrators have not implemented caring behavior. Characteristics of age, gender, tenure, education, training, work stress, nurse rewards had no influence on nurse caring behavior. Moreover, job status and motivation influenced nurse caring behavior. Nurse employment status is a determinant factor that influences nurse caring behavior. It is recommended to examine other factors that can influence the caring behavior of nurses who work at the Regional Public Hospital of East Nusa Tenggara Province.

\section{REFERENCES}

Aiken, L., Rafferty, A. M., \& Sermeus, W. (2014). Caring nurses hit by a quality storm. Nursing Standard, 28(35), 22-25. doi: https://doi.org/10.7748/ns2014.04.28.35.22.s26

Aiken, L. H., Sermeus, W., Van den Heede, K., Sloane, D. M., Busse, R., McKee, M., ... \& Tishelman, C. (2012). Patient safety, satisfaction, and quality of hospital care: cross sectional surveys of nurses and patients in 12 countries in Europe and the United States. BMJ, 344, e1717. doi: https://doi.org/10.1136/bmj.e1717

Andersson, E. K., Willman, A., Sjöström-Strand, A., \& Borglin, G. (2015). Registered Nurses' Descriptions of Caring: A Phenomenographic Interview Study. BMC Nursing, 14(16), 1-10. doi: https://doi.org/10.1186/s12912-015-0067-9

Anggoro, W. T., Aeni, Q., \& Istioningsih, I. (2018). Hubungan Karakteristik Perawat Dengan Perilaku Caring. Jurnal Keperawatan Jiwa,6(2), 98-105. doi: https://doi.org/10.26714/jkj.6.2.2018.98-105

Ariani, T. A., \& Aini, N. (2018). Nurse caring behavior and satisfaction of inpatient patients on nursing services. Jurnal Keperawatan, 9(1), 58-64.

Calong, K. A. C., \& Soriano, G. P. (2018). Caring behavior and patient satisfaction: Merging for satisfaction. International Journal of Caring Sciences, 11(2), 697703. 
Cheruiyot, J. C., \& Brysiewicz, P. (2019). Nurses' Perceptions of Caring And Uncaring Nursing Encounters in Inpatient Rehabilitation Settings in South Africa: A Qualitative Descriptive Study. International Journal of Africa Nursing Sciences, 11(100160), 1-9. doi: https://doi.org/10.1016/j.ijans.2019.100160

Demur, D., Mahmud, R., \& Yeni, F. (2019). Beban Kerja dan Motivasi Dengan Perilaku Caring Perawat. Jurnal Kesehatan Perintis (Perintis's Health Journal), 6(2), 164-176. doi: https://doi.org/10.33653/jkp.v6i2.303

Dyess, S. M. L., Prestia, A. S., \& Smith, M. C. (2015). Support for Caring and Resiliency Among Successful Nurse Leaders. Nursing Administration Quarterly, 39(2), 104-116. doi: https://doi.org/10.1097/NAQ.0000000000000101

Firmansyah, C. S., Noprianty, R., \& Karana, I. (2019). Perilaku Caring Perawat Berdasarkan Teori Jean Watson di Ruang Rawat Inap. Jurnal Kesehatan Vokasional, 4(1), 33-48. doi: https://doi.org/10.22146/jkesvo.40957

Geyer, N. M., Coetzee, S. K., Ellis, S. M., \& Uys, L. R. (2018). Relationship of nurses' intrapersonal characteristics with work performance and caring behaviors: A cross-sectional study. Nursing \& Health Sciences, 20(3), 370-379. doi: https://doi.org/10.1111/nhs.12416

Hangewa, N., Bawotong, J. S., \& Katuuk, M. E. (2020). Stres Kerja Dengan Persepsi Perilaku Caring Pada Perawat. Jurnal Keperawatan, 8(1), 59-67.

Ilmi, B. (2002). Pengaruh Stres Kerja Terhadap Prestasi Kerja dan Identifikasi Manajemen Stress yang Digunakan Perawat di Ruang Rawat Inap RSUD Ulin Banjarmasin. Thesis. Surabaya: Universitas Airlangga.

Kusnanto. (2019). Perilaku Caring Perawat Profesional. Surabaya: Pusat Penerbitan Dan Percetakan Universitas Airlangga (AUP).

Lestari, R., Kumboyono, K., \& Dyta, L. (2010). Work Stress Level and Caring Behaviour of Nurses. Jurnal Ners, 5(2), 164-170.

Mailani, F., \& Fitri, N. (2017). Hubungan Perilaku Caring Perawat dengan Tingkat Kepuasan Pasien BPJS di Ruang Rawat Inap RSUD dr. Rasidin Padang. Jurnal Endurance, 2(2), 203-208.

Mau, A., Limbong, K., \& Yetti, K. (2020). The effect of coaching and mentoring towards nurse's caring and patient satisfaction. Enfermería Clínica, 30(3), 18-22. doi: https://doi.org/10.1016/j.enfcli.2019.12.017

Miller, L. H. (1988). The Miller-Smith Lifestyle Assessment Inventory. Bookline: Biobehavioral Associates

Prihandhani, I. G. A. A. S., \& Kio, A. L. (2019). Hubungan Motivasi Kerja Perawat dengan Perilaku Caring Perawat Pelaksana di Ruang Rawat Inap Rumah Sakit Umum Wisma Prashanti Tabanan. Interest: Jurnal Ilmu Kesehatan, 8(1), 29-37. doi: https://doi.org/10.37341/interest.v8i1.114

Rizkianti, I., \& Haryani, A. (2020). The Relationship Between Workload and Work Stress With Caring Behavior Of Nurses in Inpatient Rooms. Jurnal Aisyah: Jurnal Ilmu Kesehatan, 5(2), 159-166.

Sarafis, P., Rousaki, E., Tsounis, A., Malliarou, M., Lahana, L., Bamidis, P., ... \& Papastavrou, E. (2016). The impact of occupational stress on nurses' caring behaviors and their health related quality of life. BMC nursing, 15(56), 1-9. doi: https://doi.org/10.1186/s12912-016-0178-y

Sumarni, T. S., \& Naili, Y. T. (2017). Hubungan Reward dengan Perilaku Caring Perawat Pelaksana Di Ruang Rawat Inap RSUD Ajibarang. Viva Medika, 10(1), 64-71. 
Aty, Y. M. V. B., Herwanti, E., Mau, A., Ayatullah, M. I., \& Asriwhardani, F. (2020). Factors Affecting Nurse Caring Behavior. JURNAL INFO KESEHATAN, 18(2), 171-181.

https://doi.org/10.31965/infokes.Vol18/ss2.396

| 181

Supriatin, E. (2015). Perilaku caring perawat berdasarkan faktor individu dan organisasi. Jurnal Keperawatan Indonesia, 18(3), 192-198. doi: https://doi.org/10.7454/jki.v18i3.425

Wahyudi, W. (2016). Faktor-faktor yang Berhubungan dengan Perilaku Caring Perawat di Ruang Perawatan Interna RSUD Sinjai. Undergraduate (S1) Thesis. Makassar: Universitas Islam Negeri Alauddin Makassar.

Weraman, P., \& Adoe, A. (2016). Kualitas Pelayanan Kesehatan di RSUD Kota Kupang (Deskripsi Terminologi Pelayanan Kesehatan Berbasis Sarana, SDM, dan Fasilitas di Rsud Kota Kupang) 2014. Jurnal Inovasi Kebijakan, 1(1), 31-52.

Wolf, Z. R., Colahan, M., Costello, A., \& Warwick, F. (1998). Relationship between nurse caring and patient satisfaction. Medsurg Nursing, 7(2), 99-105.

Zees, R. F. (2012). Analisis Faktor Budaya Organisasi Yang Berhubungan Dengan Perilaku Caring Perawat Pelaksana Di Ruang Rawat Inap RSUD. Prof. Dr. H. Aloei saboe Kota Gorontalo. Jurnal Health and Sport, 5(1). 